\title{
Noturno Amarelo: Um Estudo das Relações Afetivas e Espaciais em Lygia Fagundes Telles
}

\author{
Gladson Fabiano de Andrade Sousa \\ Universidade Federal do Maranhão - Brasil \\ Naiara Sales Araujo Santos \\ Universidade Federal do Maranhão - Brasil
}

Resumo: 0 presente trabalho tem como objetivo o estudo do conto "Noturno Amarelo", de Lygia Fagundes Telles, sob o aspecto simbólico da paisagem. A autora tece o drama de suas personagens envolto em sugestões e sutilezas espaciais. Seus mais diversos temas, - como morte, loucura, desencontro amoroso e vingança, emergem não apenas nos diálogos de suas personagens, mas também dos espaços carregados de simbolismo: veredas, jardins, casas, quartos, escadas... Os contos da autora são constituídos por microuniversos de tensões afetivas de latentes relações com os espaços de experiências das personagens. A análise do conto será feita a partir da perspectiva teórica do geógrafo chinês Yi-Fu Tuan, em seu livro Espaço e lugar: a perspectiva da experiência (2013) nos quais evidencia-se a ligação dos laços afetivos do homem com o meio material. Serão de pertinente contribuição também, as considerações de Gaston Bachelard sobre a poética da percepção do espaço vivido retiradas de seu livro Poética do espaço (1993). Uma vez que o conto analisado vincula-se às questões espaciais, serão utilizados os apontamentos de Maurice Halbwachs (2006) e Paul Ricoeur (2007).

Palavras-chave: Lygia Fagundes Telles. Experiência. Paisagem

Abstract: The present work aims to study the short stories "Noturno amarelo" by Lygia Fagundes Telles, under the symbolic aspect of the landscape. The author narrates the drama of her characters surrounded by suggestions and spatial subtleties. Her most diverse themes - such as death, madness, love mismatch and revenge - emerge not only in the dialogues of his characters, but also in the spaces charged with symbolism: 
paths, gardens, houses, rooms, stairs...The author's short stories are constituted by microuniverses of affective tensions of latent relations with the spaces of experiences of the personages. The analysis of the short story will be made from the theoretical perspective of the Chinese geographer Yi-Fu Tuan in his book Space and Place: the perspective of experience (2013) in which the link between man's affective ties to the material environment is evident. It will be of pertinent contribution, the considerations of Gaston Bachelard on the poetics of the perception of lived space taken from his book The poetics of space (1993). Once this short story is linked to memory and affectivity, notes on the memory of scholars Maurice Halbwachs (2006) and Paul Ricoeur (2007) will be used.

Keywords: Lygia Fagundes Telles. Experience. Landscape

As penas, sejam elas quais forem, tornamse suportáveis se as narrarmos ou fizermos delas uma história. (Dinesen Isak, 1984) ${ }^{1}$

\section{Introdução}

Com o intento de desvelar particularidades do texto da escritora Lygia Fagundes Telles, este trabalho contém um caráter primordialmente interdisciplinar. Sempre que uma perspectiva teórica de determinado autor, ou campo do conhecimento, for pertinente e coerente à análise investigativa por ora proposta, esta se fará presente. Tal metodologia abarca, a priori, a própria concepção de literatura como uma composição que vai além de representação do mundo em texto; esta seria a síntese, ou reelaboração, do plano do real. A obra não é encarada aqui como uma imitação da realidade, mas uma nova realidade autônoma que proporciona uma nova e singular experiência. É um mundo onde não se destacam as semelhanças, mas, a partir delas, produzem-se as diferenças da tessitura (Lima 1986:361). A respeito do que se faz, ou não, pertinente à análise, colhe-se em Antônio 
Cândido a relação entre a exterioridade e interioridade do que se refere à composição e exame do texto literário:

O elemento social se torna um dos muitos que interferem na economia do livro, ao lado dos psicológicos, religiosos, linguísticos e outros. Neste nível de análise, em que a estrutura constitui o ponto de referência, as divisões pouco importam, pois tudo se transforma, para o crítico, em fermento orgânico de que resultou a diversidade coesa do todo (...) a importância de cada fator depende do caso a ser analisado. Uma crítica que se queira integral deixará de ser unilateralmente sociológica, psicológica ou linguística, para utilizar livremente os elementos capazes de conduzirem a uma interpretação coerente. (Cândido 2006:16)

Elucidamos, deste modo, a concepção de que o próprio texto e a proposta interpretativa evocam suas divisões analíticas e críticas, ou seja, a estrutura constitui o ponto de referência da análise. Como objeto de análise trazemos o conto "Noturno amarelo", de Lygia Fagundes Telles, publicado, em 1977, na coletânea Seminário dos Ratos. A busca de um entendimento do conto encontra-se, de maneira fulcral, na investigação da relação entre memória e esquecimento, intimamente ligados no enredo ao aspecto espacial e simbólico (casa), social (família) e, por fim, na relação entre culpa/perdão que assola a personagem central. De modo direto, o que objetivamos alcançar é o esclarecimento de como o revisitar do passado altera tanto a percepção do próprio passado como do presente e, mais intimamente ainda, de nossa identidade. Enfim, buscamos a maneira como, no conto, a personagem consegue reconciliar-se com seu passado de modo fantástico por meio do "retorno" à casa da família, pois "conseguimos nos transformar a partir de nossas reminiscências, mesmo que essas sejam cada vez mais raras" (Santos 2003:14). Tal qual aponta a estudiosa da memória Myrian Sepúlveda dos Santos, a respeito dos estudos de Halbwachs: "o passado é continuamente reconstruído no presente" (2003: 44).

Nessa perspectiva, serão levantadas considerações dos estudiosos da memória como Halbwachs (2006) e Paul Ricouer (2007), no que diz respeito especificamente à relação entre memória, esquecimento e perdão, assim como as relações entre memória individual e memória coletiva. Uma vez que o espaço é considerado um aspecto norteador da 
reminiscência da personagem, considerações sobre o espaço do fenomenólogo Gaston Bachelard serão colhidas em sua obra A Poética do espaço (1993), assim como reflexões sobre a relação da afetividade com os espaços que habitamos do geógrafo humanista Y-Fu Tuan (2013). Não podemos ignorar a natureza da narrativa, uma vez que ela se constitui no campo do que a tradição crítica cunhou como fantástico. Ainda que não nos aprofundemos em tais questão de gênero, uma vez que não é nosso foco, alguns apontamentos nos ajudarão a compor uma melhor coesão analítica.

\section{Apontamentos da poética de Lygia Fagundes Telles}

A autora paulista, ganhadora do prêmio Camões de 2005, um dos maiores prêmios de literatura de língua portuguesa, é possuidora de uma narrativa fluida e límpida, pautada na oralidade e diálogos repletos de tensões e possibilidades interpretativas. 0 estado psicológico de suas personagens é desvelado sem cair em psicologismos e longas digressões intimistas: sentimentos e estado de espírito surgem em uma simples ruga que salta aos olhos. Aqui, chamamos atenção para um aspecto central dos contos lygianos: todo o universo narrativo construído caminha na direção de seu efeito final, constituindo-se um microuniverso coeso: tema, tons, diálogos, gestos e, principalmente, o espaço surgem como sugestão do propósito final do conto. Neste ponto, podemos afirmar que Lygia é tributária das ideias do conto moderno, ao estilo de Edgar Allan Poe, pois uma vez que se concebe com zelo deliberado um certo efeito único ou singular para manifestá-lo, serão inventados incidentes que se combinarão da melhor forma para que ajudem a estabelecer esse efeito preconcebido (Poe 1999). Pela própria contensão que o gênero exige, nada é posto no conto, de maneira direta ou indireta, que não esteja em função do desígnio preestabelecido; nada no conto de Lygia é dispensável, tudo é necessário à construção de uma atmosfera dramática que caminha na intenção do plot.

O conto a ser analisado gira em torno da personagem Laura, que busca redenção de um passado cheio de culpas. O seu presente é atormentado pelos erros cometidos em seu passado. Porém, como mudar um passado distante no tempo e espaço? 0 conto se inicia com Laura e o atual namorado, Fernando, com o carro quebrado no meio de uma estrada 
cercados por denso matagal. A consciência culpada de Laura não é dada ao conhecimento imediato do leitor, que vai tomando consciência no decorrer do conto por meio das descrições, dos diálogos desencontrados e ações reticentes das personagens. 0 que o leitor descobre depois como sendo culpa, de início, surge como insatisfação da personagem, inquietação com o presente e principalmente com o atual relacionamento: "Gostaria de estar numa nave, mas com o motor desligado, sem ruído, sem nada. Quieta. Ou nesse carro silencioso, mas sem ele" (Telles 2009:123). Aos moldes do conto moderno de efeito intenso seria apresentada uma elaboração de começo, meio e fim, matematicamente, bem definidos. Porém, em Lygia, o leitor tem a sensação de pegar a história no meio, no ato de seu desenvolvimento. Um conto de ambientação a construir, de maneira paulatina.

No conto por hora analisado, o clima já aparece no título, que serve como eixo simbólico de toda a narrativa. Apesar do "amarelo" ser uma cor quente, usado para adjetivar "noturno", ganha tom soturno, como o amarelar de uma fotografia envelhecida. 0 conto é permeado de alusões a tal ideia: "queixo sépia" (Telles 2009: 127); "suéter amarelo" (ibidem: 127); "O vestíbulo de paredes forradas com o desbotado papel bege, salpicado de rosinhas pálidas" (ibidem: 126); "sapatinhos da cor do papel da parede" (ibidem: 127). Na perspectiva adotada, a expressão "noturno amarelo" vai além do sentido de culpa ou melancolia. A personagem faz uma passagem para o passado, a fim de se reconciliar com os habitantes de sua antiga casa. 0 tom amarelado é a própria distensão temporal simbolizada.

Na poética de Lygia Fagundes Telles ${ }^{2}$ diversos elementos da estrutura narrativa sugerem carga simbólica. Um dos maiores símbolos de sua escrita é o frequente uso da cor verde e nem sempre com o mesmo sentido. Cada uso é ressignificado dentro do drama narrado: inveja verde transbordando espessa, como em a "Estrutura da bolha de sabão" (2010), mistério e renascimento como em "Natal na Barca" (2009), ou ainda, o vínculo silencioso entre esperança e morte, como em "Antes do baile verde" (2009). A elaboração simbólica é uma extensão da própria espécie de intimismo que sua poética desenvolve: intimismo das superfícies, os melindres de pequenos gestos, descrições e ações. As personagens não entram em profundo êxtase intimista como é comum nas personagens de Clarice Lispector, por exemplo, suas reações viscerais são constantemente abafadas. 
Há em LFT uma contínua sobreposição de planos narrativos e desencontros. Em 1958, a autora publicou um conjunto de contos sob o título Histórias do Desencontro. Sobre este tema Fábio Lucas aponta que:

Lygia Fagundes Telles tem a arte de construir situações humanas, principalmente amorosas, plenas de expectativas, mas quase sempre atingidas de modo dramático pelo desencontro. Há um determinismo cruel a condenar as suas criaturas ao insucesso. (1999: 67)

Uma das maneiras que a autora encontra para expressar determinado descompasso é, enquanto duas personagens conversam em discurso direto sobre um assunto, o tema verdadeiro que o conto pretende desenvolver está encoberto. Interrompe-se este primeiro plano narrativo em discurso direto com falas repentinas e entrecortadas do segundo plano encoberto, tácito, como se o pensamento da personagem, todo tempo presente e inquieto, viesse à tona, interrompendo o diálogo que serve como subterfúgio. Recurso utilizado em vários outros contos seus, como "Antes do baile verde" (2009), no qual a personagem Tatisa se prepara para o carnaval enquanto o pai está moribundo no quarto ao lado. Conversa-se sobre o carnaval e, repentina e aparentemente sem contexto, surgem perguntas sobre o pai moribundo.

O teórico argentino Ricardo Piglia (2002) aponta tal diálogo constante entre dois planos narrativos paralelos como chave central da construção de um conto. Assim, o conto conta sempre duas histórias, uma contada em primeiro plano (história aparente), ocultando em seu interior a segunda história (história cifrada): "A história visível esconde uma história secreta, narrada de forma elíptica e fragmentária” (Piglia 2002: 59). Em "Noturno amarelo", a maior culpa que Laura carrega: o caso com o noivo de sua prima e a consequente tentativa de suicídio dele, depois que Laura o abandona, em meio a conversas díspares, surge repentinamente: "Acho que esse ponto é o mesmo da manta que fiz pra Avó, lembra? Só que usei uma lã mais grossa. Acho lindo xale branco, fiz pra dona Eduarda com linha de seda. Interrompi seu devaneio, mas e o Rodrigo?" (Telles 2009:123).

Sobre a sintaxe de LFT, é interessante observar alguns aspectos pertinentes para a construção final de sentido do conto. Embora possa adotar o foco narrativo em terceira 
pessoa como um narrador observador, frequentemente, surge o discurso indireto livre, enlaçando as vozes do narrador as das personagens, conferindo ambiguidade ao texto. Em "Noturno amarelo", ocorre que a personagem narra sua história, porém o desagrado na relação que vive no presente é transmitido ao leitor quando esta coloca em sua voz frases do namorado, o discurso entra de forma direta.

Fernando arrancou o paletó no auge da impaciência e perguntou com voz esganiçada se eu pretendia ficar a noite inteira ali de estátua, enquanto ele teria que encher o tanque naquela escuridão de merda, porque ninguém lhe passava o raio da lanterna. Inclinei-me para dentro do carro de portas escancaradas, outra forma que ele tinha de manifestar o mau humor era deixar gavetas e portas escancaradas, que eu ia fechando em silêncio, com ódio igual ou maior. Fiquei olhando o relógio embutido no painel. (Telles: 2009: 123, grifo nosso)

Em “Noturno amarelo", há constantemente a tensão temporal passado-presente, de diversas maneiras articulada: como símbolos, tal qual já foi analisado no próprio título do conto, como visita fantástica à casa do passado ao adentrar uma vereda, ou ainda ao olhar constantemente o relógio. A sintaxe lygiana no conto também alude à relação tempo-espaço do passado-presente:

Quando me lembro dessa noite (e estou sempre lembrando) me vejo repartida em dois momentos: antes e depois. Antes, as pequenas palavras, os pequenos gestos, os pequenos amores culminando nesse Fernando, aventura medíocre de gozo breve e convivência comprida. Se ao menos ele não fizesse aquela voz para perguntar se por acaso alguém tinha levado a sua caneta. Se por acaso alguém tinha pensado em comprar um novo fio dental, este estava no fim. Não está, respondi, é que ele se enredou lá dentro, se a gente tirar esta plaqueta (tentei levantar a plaqueta) a gente vê que o rolo está inteiro mas enredado e quando o fio se enreda desse jeito, nunca mais!, melhor jogar fora e começar outro rolo. Não joguei. Anos e anos tentando desenredar o fio impossível, medo da solidão? Medo de me encontrar quando tão ardentemente me buscava? (Telles 2009: 123, grifos nossos)

O desencontro em "Noturno amarelo" assume caráter de diálogo-monólogo. Laura fala com Fernando e suas frases apresentam ambiguidades; em um plano fala com o companheiro, do qual tem desejo de ver-se livre, no outro plano fala consigo a respeito da 
solidão que sente. 0 problema do fio dental enrolado dentro do próprio recipiente é metáfora de sugestão ambígua para o próprio relacionamento: "Já fazia algum tempo que queria estar sem ele, mesmo com o problema de ter acabado a gasolina" (Telles, 2009:123). Nota-se, na ambiguidade, que o fluxo passado-presente também se encontra neste ponto, pois a todo momento os discursos do passado misturam-se com o presente.

\section{A Topografia da Memória, do esquecimento e do perdão}

Uma vez pontuados os procedimentos técnicos e suas consequências semânticas e discursivas dentro da narrativa, passemos, sem abandonar o que já foi ponderado, para a análise da expiação da personagem principal pelo viés que relaciona espacialidade e memória.

De início, é apresentada a situação do carro com problemas na estrada, rodeada por densa mata, Laura demonstra introspecção fitando a noite estrelada, mas sem lua. Ao leitor não é dado reconhecer, inicialmente, nem a profundidade nem os motivos da inquietude da personagem. A revelação só ocorrerá a partir da visita insólita à casa da família, com os diálogos que mantém com seus entes e, com cada um, possui alguma culpa a redimir-se. Laura adentra a mata guiada pelo cheiro da flor que reconhece imediatamente: "Dama-danoite - eu disse respirando de boca aberta o perfume que o vento trouxe de repente. - E vem daquele lado" (Telles 2009: 123). A flor que LFT escolhera para guiar a personagem mata adentro é a Dama-da-noite, flor que possui variedades amarelas e brancas, que ajudam a compor o campo semântico sépia do conto. Sua presença é perfeitamente alinhada com o desenvolvimento da narrativa, se lembrarmos que a Dama-da-noite (Cestrum nocturnum ${ }^{3}$ ) é uma planta tóxica de efeitos alucinógenos.

O caráter fantástico da passagem de Laura do plano do presente, onde o carro se encontra, para a casa de seu passado, é descrito como um entorpecer, um transe a seguir o inconfundível perfume que essa flor exala no período noturno. Laura segue o perfume para outro plano. 0 perfume da flor fica mais pesado enquanto ela "ia ficando mais leve" (Telles 2009: 124). 0 perfume desaparece logo que Laura chega à casa da família, como se guiá-la fosse a sua exclusiva função. Sugestão onírica, ou alucinógena, um estado de transe em 
direção ao passado ou, ainda, uma espécie de campo de papoulas com o adormecer da consciência, como Dorothy em $O$ mágico de oz.

Em retrospecto, Laura, ao falar sobre aquela noite, declara que está sempre lembrando e se vê "repartida em dois momentos: antes e depois" (ibidem). Algo de significativo operou tal lapso, quebra, ou ainda superação, naquela noite que visitara aquela “...casa fora do tempo, mas dentro do jardim" (ibidem). Desconsidera-se o tempo que transcorre a visita: nove horas o relógio marca na antiga casa, a mesma hora quando ela retorna à estrada. Como já afirmado, em toda a construção narrativa, a autora caminha em direção ao propósito do conto, não é senão nesse sentido que se narra:

E atravessei a faixa de mato rasteiro que bordejava o caminho, a barra do meu vestido se prendendo nos galhinhos secos, poderia arregaçá-lo mas era excitante me sentir assim delicadamente retida pelos carrapichos (não eram carrapichos?) que eu acabava arrastando. Segui pela vereda. Tão familiar. Como a casa lá adiante, lá estava a casa alta e branca fora do tempo mas dentro do jardim (Telles 2009: 125).

Se considerarmos como centro do enredo o mote da expiação da personagem, a alegoria da vereda de carrapichos, "espinhos", que lhe dilaceram a própria carne, alude à via crucis. Travessia pela qual a personagem passará até chegar à antiga casa de seus parentes. Sua peregrinação passa por cada pessoa e, a cada um destes, um pecado de seu passado, do qual busca redenção. Ofereceu-se para levar a empregada da casa, Ifigênia, à Aparecida, a fim de cumprir uma promessa, mas jamais a levara. Prometera dar à Ducha, sua irmã mais nova, um espelho grande para que pudesse praticar ballet, em troca de um suéter amarelo. Ficara com o suéter, jamais dera o espelho. Trapaceou no xadrez em sua última partida com o avô. A avó ficou doente, porém nunca a visitara. E, por fim, a culpa que liga todo o enredo: teve um caso com Rodrigo, o namorado de sua prima, Eduarda, e depois o abandonara. Como consequência, Rodrigo dera um tiro no próprio peito. Esta, a maior culpa que Laura carrega, atravessa o enredo, pois é sobre esse assunto que as personagens mantêm um silêncio. 0 discurso é construído em sutil jogo narrativo de sugerir, mostrar aos poucos e esconder. As personagens nunca são diretas, como demostrado no trecho: 
Andava com dificuldade, as pernas curtas, inchadas. Ficamos um instante na varanda e sem saber por que (na hora não soube por que) evitei ficar muito exposta na luz da janela. Puxei-a para mais perto de mim:

- Estão todos aí?

Ela respondeu num tom secreto:

- Só falta o Rodrigo.

Apoiei-me na coluna. (Telles 2009: 125)

Não sabia o porquê evitava entrar na casa, mas surge, em tom secreto, o nome de Rodrigo pela primeira vez no conto. 0 abalo de ouvir o nome é demonstrado no ato de apoiar-se na coluna, mais uma vez evidenciando que, em LFT, os gestos possuem destaque para o entendimento das emoções das personagens.

Neste sentido, analisemos três elementos norteadores do enredo. Primeiramente a questão da distensão do tempo, que se encara como o ser que se localiza em um presente que é passado e ao mesmo tempo futuro. Em seguida analisaremos a fenomenologia da casa e do jardim em suas dimensões simbólicas. O tempo e espaço, no conto, são condensados em: “...lá estava a casa alta e branca fora do tempo mas dentro do jardim" (Telles 2009:125, grifo nosso).

A narratividade concebe a aquisição do ser enquanto tal pela possibilidade do relato. O tempo torna-se humano e possibilita a construção identitária, à medida que é formada e reformulada pelo ato de narrar. Como apontou Paul Ricouer, em Tempo e narrativa (1994: 9), o mundo exibido por qualquer obra narrativa é sempre um mundo temporal: “O tempo torna-se humano na medida em que está articulado de modo narrativo; em compensação, a narrativa é significativa na medida em que esboça os traços da experiência temporal". Articulando tal concepção de apropriação do tempo pelo homem na condição de sua narratividade, podemos parafrasear a declaração da personagem, repito: “...lá estava a casa alta e branca fora do tempo mas dentro do jardim" (Telles 2009: 125, grifo nosso), do seguinte modo: lá estava o meu lugar, lugar de memória, de afetividade, e, até de inevitáveis desafetos, em suma, lugar de experiência de meu ser-estar-no-mundo, que se coloca antes no espaço valorizado, que no tempo. 
Laura (re)coloca-se em tempo narrativo ao revisitar se suas memórias. Mas como revisitar o passado sem sair do presente? Ou ainda, como ir a um lugar fora do tempo, mas dentro do jardim? Analisemos a expressão "fora do tempo", considerando que somente para a personagem o tempo transcorre, pois, como já afirmado, no plano narrativo que se passa na estrada deserta, o tempo não transcorre. Esta é exatamente a hora quando regressa ao carro, fazendo o leitor inferir que não se passou tempo algum em toda a visita à antiga casa de sua família. Retomando Confissões, de Agostinho, Paul Ricouer (1994) coloca a questão: o que é o tempo?

0 tempo não tem ser, posto que o futuro ainda não é, que o passado não é mais e que o presente não permanece. E contudo, falamos do tempo como tendo ser: dizemos que as coisas por vir serão, que as coisas passadas foram, e que as presentes, passam. (Ricouer 1994: 20)

Ricouer afirma que é o uso da linguagem que sustenta a tese do ser do tempo. Porém, o paradoxo se apresenta: mas como o tempo pode ser, se o passado não é mais, se o futuro não é ainda e se o presente nem sempre é? (Ricouer 1994). Desta questão sai o tema da distensão do tempo, que responde à pergunta: cem anos podem estar presentes ao mesmo tempo $?^{4}$ A distensão encontra-se em tríplice presente, encontra-se na alma um presentefuturo, presente-presente, presente-passado, em permanente diálogo. 0 presente-futuro estaria na espera, o presente-presente, na atenção e, finalmente, o presente-passado, na memória.

O passado que a personagem Laura visita, seria então a distensão (distentio) de sua alma que caminha angustiada a espera, espera do conserto do carro e desprazer da companhia, da qual deseja livrar-se. É uma incômoda atenção da qual ambiciona desprender-se, uma realidade presente que deixou de ser companhia e agora é solidão a qual lhe remete à memória e dela submerge a culpa por suas promessas não cumpridas, por sua traição, e por abandonar o namorado. 0 resultado desta dialética temporal é a mudança da atenção (presente-presente) pelo reconciliar com suas memórias (presente-passado). Sucintamente, nas palavras de Ricouer: "É, pois, na alma, a título de impressão que a espera 
e a memória tem extensão. Mas a impressão só está na alma enquanto o espírito age, isto é, espera, está atento e recorda-se" (Ricouer 1994: 24).

É na alma que se passa a ação do alongamento de um passado, o u o encurtamento do futuro; a ação do ser configura-se como ato primordial para tal processamento dinâmico: "Quanto mais a ação avança, mais abrevia a espera e alonga-se a memória" (Ibidem: 24). Assim, encontra-se a possibilidade de uma transformação do passado ou, em outros termos, um reconciliar com o passado. 0 fenômeno da memória não é inalterável, a expiação da personagem por cada confissão transforma a percepção do passado, pois como descreve: “era nova essa noite antiga (...) Noite dentro da noite” (Telles: 2009: 129).

Paul Ricouer, ao tratar das questões de anistia e perdão, propõe um diálogo entre o ato de lembrar e de esquecer. Esta relação é determinada segundo os interesses do presente. Assim, anistia não é perdão. 0 perdão não é institucionalizado, não está previsto em lei; esta configura a anistia, uma vez que desse modo seria uma trégua à força. A anistia é um esquecimento imposto, para que a sociedade possa continuar seu cotidiano. A exemplo, temos as inúmeras ditaduras, como no Brasil ou Chile, que decretaram anistia logo após suas quedas. Enquanto imposição, a anistia impede a reelaboração do passado, logo impede o perdão: A anistia impediria o perdão. Para haver perdão, é preciso remover mágoas. Portanto, só a narrativa e a memória permitem o perdão (Studart 2012). Assim, afastando a ideia comum que perdoar é esquecer, em Ricouer, configura-se justamente o oposto, o ato de perdoar está diretamente ligado à uma memória. Ricouer admite o papel do outro em relação ao ato de recordar de um indivíduo, a intersubjetividade marca a formação relacional, pois

Mesmo antes de ser um indivíduo, um “eu”, já está em certo nível imerso na placenta de uma memória que o socializa e à luz da qual ele irá definir seu conjunto de valores e representações coletivas. Para Ricoeur, recordar é em si mesmo um ato relacional, que ele define por "alteridade". (Ricouer apud Studart 2012)

Notamos assim a integração de uma memória individual e uma memória coletiva, que está no centro da temática do perdão focada na presente análise, posto a personagem 
Laura, em sua culpabilidade, busca o reencontro com a família como ação de expiação. Socialmente, admitindo em ato de linguagem sua culpa, reelabora suas percepções do passado.

Afirmando dependência da memória individual e da memória coletiva, Ricouer dialoga com as ideias do sociólogo francês Maurice Halbwachs, o qual, em sua obra Memória coletiva (2006), evidencia a integração entre o indivíduo e a coletividade, uma vez que a memória do eu não dependeria exclusivamente das recordações próprias, mas sim da dinamicidade do diálogo com o coletivo. Em outras palavras, "nossa recordação será maior quando se apoia nas memórias de muitos outros" (Halbwachs 2006:25). Deste modo, se entendermos o perdão como o processo do ato de linguagem que perpassa as reconfigurações da memória traumática, a aceitação da culpabilidade, então, tem como premissa a confissão, esta narrativa é premissa da reconfiguração das relações com o outro, e, principalmente, consigo mesmo. Fica evidente o ritual que Laura cumpre em "Noturno amarelo": o presente se transforma ao final deste processo narrativo-expiatório:

Se o que vemos hoje toma lugar no quadro de referências de nossas lembranças antigas, inversamente essas lembranças se adaptam ao conjunto de nossas percepções do presente. É como se estivéssemos diante de muitos testemunhos. Podemos reconstruir um conjunto de lembranças de maneira e conhecê-lo por que eles concordam no essencial, apesar de certas divergências. (Halbwachs 2006: 25)

As memórias do passado não são estáticas, não só o presente muda, mas a própria percepção dos fatos do passado. Como recurso para se ter uma nova perspectiva a respeito de um evento ocorrido, recorre-se à reconstrução narrativa, ideia aludida na epígrafe posta no início deste estudo: inteligível e suportável é a pena narrada (Ricoeur 2003). Intenta-se, nesta coerência narrativa, a reconstrução de uma perspectiva afetiva sobre um evento traumático, ou seja, a alteração de como o sujeito reage às tais memórias quando são evocadas. A própria identidade faz parte deste jogo narrativo, pois, como aponta Paul Ricouer (2007), o sujeito constitui-se enquanto tal, à medida que se coloca em tempo narrativo.

Vejamos o ritual do perdão pela confissão. Quando finalmente encontra a prima, 
Laura narra: "Encarei Eduarda, pela primeira vez realmente a encarei, mas era preciso falar? Era mesmo preciso?" (Telles 2009:131). Então, inicia-se longa declaração de sua culpa por ter tido um caso com o namorado da prima: "Eduarda, diga que acredita em mim, diga que acredita! " (Ibidem).

A peregrinação da personagem Laura se passa no adentrar do jardim e de sua casa. "Jardim" tem significação especial dentro das narrativas de LFT. Inúmeras narrativas se passam em jardins, como “A mão no ombro” (2009), "Lua crescente em Amsterdã” (2009), "Herbarium” (2009), “A caçada” (2009). Jardim, muito além de um simples cenário, é um lugar em que as personagens se conflitam e se chocam com as verdades que, embora pareçam evidentes - como o destroçar do primeiro amor em "Herbarium" (2009), ou como a irreversibilidade do tempo com a chegada da morte em "A mão no ombro" (2009) -, o ser humano insiste em silenciar.

Vejamos o vínculo da afetividade a partir de um espaço social e físico: a família. A família então é a primeira sociedade à qual pertencemos, é em seu seio que desenvolvemos as primeiras relações afetivas, e seu útero é a casa: “A casa está no centro do mundo, ela é a imagem do universo" (Chevalier/Gheerbrant 1998: 235). A casa significa o interior do ser. Segundo Bachelard (1993), seus andares, seu porão e sótão simbolizam diversos estados da alma. Em sua fenomenologia do habitar, examina as "imagens do espaço feliz" (Bachelard 1993:19), espaços de intimidade integrantes da vivência humana que ensejam sentimentos e lembranças.

A casa, enfim, é um verdadeiro cosmos, o abrigo primordial do homem, o nosso primeiro universo. Segundo o autor "a casa é uma das maiores forças de integração para os pensamentos, as lembranças e os sonhos do homem" (Bachelard 1993:26). Então, o regresso da personagem Laura à casa familiar - "Segui pela vereda. Tão familiar. Como a casa lá adiante" (Telles 2009: 125) - é um retorno a si mesma, em sua interioridade em estado mais puro. Repara-se um passado pelo regresso à intimidade do ser, assim evidencia-se a sua peregrinação. Adentrar o jardim e a casa é, em última estância, o adentrar no mais íntimo do ser.

Muitas vezes, utilizamos os conceitos de espaço e lugar como sinônimos, fazendo, 
inclusive, uso indiscriminado de ambos. Porém, para a Geografia Humanista, estes, ainda que mantenham íntima interrelação entre si, não se confundem. Seguindo as orientações teóricas de Yi-Fu Tuan, evidenciadas no livro Espaço e Lugar: a perspectiva da experiência (2013), espaço é um conceito amplo, pois é um domínio para o qual o ser humano não estabeleceu nenhum vínculo. Ao espaço, como configura não um ponto, mas uma série de pontos, atribuímos propriamente a sensação de amplitude, liberdade.

Na experiência, o significado de espaço frequentemente se funde com o de lugar. "Espaço" é mais abstrato do que "lugar". O que começa como espaço indiferenciado transforma-se em lugar à medida que o conhecemos melhor e o dotamos de valor. (Tuan 2013:14)

Conforme percebemos, as ideias de espaço e lugar estão intimamente ligadas. Não podemos definir um sem o outro. Significativamente, a partir da segurança e estabilidade do lugar, criamos consciência da amplitude, da liberdade e da ameaça do espaço, e vice-versa. Para Tuan (2013), o lugar está diretamente ligado à ideia de segurança. Para a personagem Laura, a liberdade sem limites da estrada, no início do conto, é ameaçadora, liberdade de um território indefinido, não significado. Nota-se que, em sua imaginação, a segurança, o lugar, seria estar trancada em uma nave espacial à deriva e sem o atual namorado. Ainda mais, o seu lugar, perpassado por afetividade e reconhecimento, é a vereda tão familiar que a leva até a casa de seu passado, casa igualmente atribuída das qualidades de lugar, atestadas por Tuan.

Transpassar a vereda, pelo jardim, é a purificação de um novo tempo. Simbolicamente tal purificação, com traços ritualísticos cristãos, é sugerida também em dois elementos que se cruzam sutilmente no enredo: a cereja e a cor roxa.

Vi que a Avó me chamava para sentar a seu lado no banco do piano e vi ainda num relance, atrás do piano, o grande relógio marcando nove horas. No copo, o ponche com a cereja descaroçada, exposta, boiando na superfície roxa.

- Vamos, beba, não tem veneno - ordenou Eduarda e seu riso era tão confiante que achei injusto que o tempo continuasse e quis correr e agarrar o pêndulo, pára! Esvaziei o copo trincando nos dentes a 
cereja cristalizada com pedaços de outras frutas que não identifiquei, Eduarda guardava o mistério dos ingredientes. (Telles 2009: 130)

No copo de ponche que Eduarda preparou e ofereceu à Laura, há uma cereja descaroçada, tal fruto é ligado tanto à sensualidade, quanto à juventude ${ }^{5}$, mas também à efemeridade destas. Lembremos outro conto de LFT, As cerejas (2009), no qual o rito de passagem à maturidade é o simbolismo central. Romper a polpa vermelha da cereja para alcançar o caroço duro, simboliza o sacrificar de sangue e carne para alcançar a pedra fundamental da pessoa humana (Chevalier/Gheerbrant 1998 :276). A bebida com a cor roxa simboliza purificação. Basta lembrarmos o uso comum da cor roxa na liturgia católica nos tempos de Quaresma, tempo de penitência e purificação. Eduarda, aquela que guarda o mistério dos ingredientes, oferece o cálice da nova aliança à Laura, que se redime de seus pecados. A culpa que mais pesa à Laura no conto é ter seduzido e, logo em seguida, abandonado Rodrigo, noivo de sua prima Eduarda. Rodrigo, que tentara suicídio com um tiro no peito, no revisitar de Laura, pega um copo de ponche e a faz beber:

- Eu te neguei, Rodrigo. Te neguei e te trai e traí Eduarda. Mas queria que soubesse o quanto amei vocês dois. (...)

- Se a gente não trair os mais próximos, quem então vai trair? (Ficou sério.) - Éramos muito jovens.

- Passei a noite me desculpando, só faltava você, oh Deus! Como eu precisava desse encontro - disse, tocando no seu peito.

Ele estremeceu. Então me lembrei, mas ainda dói, Rodrigo? E continuam as bandagens? Ele pegou um copo de ponche, me fez beber. (Telles 2009:136)

0 ritual fora cumprido: logo após a confissão, a comunhão, tanto em sentido de identificação, união com o outro, quanto no sentido eucarístico.

Durante todo o processo de expiação, Laura depara-se com a figura singular de sua irmã mais nova, Ducha, que serve como arauto dos pecados de Laura: suas ações de lépida bailarina e falas jocosas assemelham-se à figura do bobo da corte, figura a quem era legada a função de entreter o rei, mas também era o único que podia criticá-lo, fazendo-o rir, pois era considerado louco ou tolo. Seguindo a tradição da máxima latina, Ridendo Castigat 
Mores, 6 Ducha expressa, a exemplo do teatro de Gil Vicente ou novelas filosóficas de Voltaire, críticas sempre com tons burlescos.

Roubou a torre do Avô! Roubou a torre do Avô! - gritou Ducha aproximando-se num salto e fugindo de novo, espavorida, de braços abertos e curvada como que impelida por uma ventania: - Ficou com meu espelho e com a torre do Avô! (Telles 2009: 130)

Em todo o conto, tal arauto torna públicas as faltas cometidas por Laura: "Não veio buscar Ifigênia que queria cumprir a promessa, não trouxe meu espelho, roubou a torre do avô, roubo o noivo de Eduarda e não visitou a Avó! (Telles 2009: 130). Longe de ser inocente, Ducha apresenta-se como a mais astuta das personagens. Lygia coloca a pequena irmã como guia da expiação, como promotora dos pecados de Laura. Seu papel, com dissimulada inocência e ironias, é de guiar Laura nas veredas de sua expiação. Ducha conhece o caminho, como, Dom Bibas, o bobo, conhecia e guiou os soldados de Afonso Henriques pelo Castelo de Guimarães, no romance de Alexandre Herculano. Com tom jocoso, Ducha, que encarna a figura do bobo, que pode-se dizer alter ego de Laura, diz aquilo que ninguém mais ousa:

- E ainda por cima faz a femme fatale - acrescentou Ducha rapidamente, com o gesto de quem empunha uma arma e aponta contra o peito. Acionou o gatilho. - Pum!... (Cambaleou, esboçando o movimento de se desvencilhar da arma. Estendeu-se no almofadão, a mão direita apertando o peito... (Telles 2009:135)

A imagem do bobo não permanece apenas na referência do comportamento, Ducha é descrita ironicamente como "um pajem medieval" (Telles, 2009, p.137). Ao final do conto, cada parente some na porta do fundo da sala e, logo após, a própria casa também desaparece.

Para vislumbrarmos a conclusão do conto, que se dá em meios fantásticos, busquemos algumas contribuições para o entendimento deste gênero nos teóricos Tzvetan Todorov e Filipe Furtado. Para Todorov, “o entendimento alegórico ou poético do enredo mataria o próprio fantástico" (1992: 32-33), pois não haveria hesitação, a qual, para o 
teórico búlgaro, é condição de existência do fantástico. Tudo o que seria sobrenatural é entendido de maneira figurativa. 0 adentrar de Laura na casa de seu passado, com a expressiva descrição onírica e diversas passagens, como o sumir repentino da casa e de seus parentes, fosse entendido como alegorias, mataria o efeito fantástico do encerramento do conto. Todos esses elementos fazem com o que o leitor seja direcionado - e até este ponto da narrativa - a considerar obra como um delírio ou sonho. Laura adormecera no carro? , o leitor é levado a perguntar-se. Todorov (1992) ainda evidencia as "desculpas" que faria o gênero fantástico se desfazer, como as explicações do evento sobrenatural como fruto de uma imaginação desordenada por sonho, loucura ou drogas.

O teórico português Filipe Furtado, em sua obra A construção do fantástico (1980), afirma que a relação do fantástico com o real é de difícil equilíbrio. É ameaçador ao fantástico a racionalização pura do evento sobrenatural, explicação que não deixaria abertura para a possibilidade de existência de outra explicação. A narrativa fantástica procura envolver o leitor em credibilidade, exacerbar de todas as formas a sua verossimilhança (racionalidade parcial), porém, para logo "escamotear, ou alterando dados necessários à decisão do destinatário do enunciado" (Furtado 1980: 45). Assim, a falta de racionalização parcial elimina o fantástico, uma vez que o evento que é estranho à realidade das personagens precisa de um paradigma de realidade para lhe ser alheio. Então, o que chamou de difícil equilíbrio da literatura fantástica, são as inúmeras estratégias de que o escritor lança mão, primeiro para colocar o leitor/personagem em um mundo o mais real possível e depois subvertê-lo com o evento insólito:

O fantástico apresenta "uma organização dinâmica de elementos que, mutualmente combinados ao longo da obra, conduzem a uma verdadeira construção de equilíbrio difícil, (...) é da rigorosa manutenção desse equilíbrio tanto no plano da história como no do discurso, que depende a existência do fantástico na narrativa. (Furtado 1980: 15)

O fantástico, assim, seria o gênero que vai além da hesitação das explicações do fenômeno estranho à realidade, mas sim aquele que mantém a porta aberta para ambas as explicações. No conto analisado, Laura volta ao carro, e o namorado não notara a sua 
ausência. Marca-se a mesma hora que ela saíra. Passara tudo na imaginação da personagem? Porém, LFT volta a desestabilizar tal possibilidade quando coloca um elemento vindo da visita insólita do passado no presente narrado. Dentro do carro, Laura fecha “com força a argola de Eduarda que ainda trazia na mão." (Telles 2009: 138).

É comum, em LFT, os enredos cíclicos: inícios que de alguma maneira regressam ao final. Denso de referências simbólicas, o conto dá ao leitor a sugestão do renascimento da personagem. No início do conto, Laura observa: “Através do vidro, a estrela maior (Vênus?) pulsava reflexos azuis” (Telles 2009: 123). Vênus carrega consigo a simbologia da passagem dos estados de morte e vida: "O ciclo diurno de Vênus, que aparece alternadamente no oriente e no ocidente (estrela da manhã e estrela da tarde), faz dele um símbolo essencial da morte e do renascimento" (Chevalier/Gheerbrant 1998: 937). Ao final do conto, dentro do carro, Laura declara-se feliz e fica observando a Via Láctea (do grego, "o caminho de leite”), bebida ligada aos que nascem. Seu simbolismo está ligado aos iniciados ou aos que nascem novamente. Deste modo, encerra-se o ritual que possibilitou Laura reconciliar-se com o passado.

\section{NOTAS}

\footnotetext{
1 Apud in ARENDT. H, Daguerreotypes and Other Essays, Dinesen Isak. Chicago: University of Chicago Press 1984 edition

2 Referida LFT posteriormente.

${ }^{3}$ Fonte: http://aquabiotech2.tripod.com/id5.html, acesso em: 20 de setembro de 2017.

${ }^{4}$ Agostinho, Confissões, Livro XI. Santo. São Paulo: Paulus, 1995

5 Fonte: https://www.dicionariodesimbolos.com.br/c ereja/. Acesso em 20/09/2017

${ }^{6}$ Corrige os costumes sorrindo
} 


\section{Bibliografia}

Bachelard, Gaston (1993), A poética do espaço, São Paulo, Martins Fontes.

Candido, Antônio (2006). Literatura e sociedade, Rio de Janeiro, Ouro sobre Azul.

Chevalier, Jean/Gheerbrant, Alain (1998), Dicionário de Símbolos. Rio de Janeiro. José Olympio.

Furtado, Filipe. A Construção do Fantástico na Narrativa, Lisboa: Livros Horizonte, 1980.

Halbwachs, Maurice (2006), A memória coletiva, 1aEd. São Paulo, Centauro.

Herculano, Alexandre (1967) O bobo, São Paulo, Difusão Europeia do Livro.

Lima, Luiz Costa (1986), Sociedade e discurso ficcional, Rio de Janeiro: Guanabara.

Piglia, Ricardo (2002), Teses sobre o conto, in: Formas Breves, São Paulo, Ed Cia das Letras. Poe, Edgar Allan (1999). Poemas e Ensaios, São Paulo, Ed. Globo.

Ricoeur, Paul (2007). A memória, a história, o esquecimento, Campinas: Ed.da UNICAMP. . Memória, história, esquecimento. Conferência escrita e proferida em inglês em: 8 mar.

2003, em Budapeste, sob o título: "Memory, history, oblivion". Disponível em: http://www.uc.pt/fluc/lif/publicacoes/textos_disponiveis_online/pdf/memoria_historia. Acesso em 15/01/2017)

Santos, Miriam Sepúlveda dos (2003), Memória Coletiva e Teoria Social, São Paulo, Annablume.

Studart, Hugo. A memória, o perdão e o esquecimento - ou a dor de sentir a presença da ausência. (2012), Disponível em: http://studart.blog.br/index.php/a-memoria-o-perdaoe-o-esquecimento-ou-a-dor-de-sentir-a-presenca-da-ausencia/.

Telles, Lygia Fagundes (2009). Antes do baile verde. Rio de Janeiro, Ed. Cia das Letras.

-- (2009). Seminário dos Ratos. Rio de Janeiro, Ed. Cia das Letras.

N. 38 - 6/ 2018 | 407-427 - ISSN 2183-2242 | http:/dx.doi.org/10.21747/21832242/litcomp38v6 
Todorov, Tzvetan (1992), Introdução à literatura fantástica. São Paulo, Perspectiva.

Tuan, Yi-Fu (2013), Espaço e lugar: a perspectiva da experiência, Londrina, Eduel.

Gladson Fabiano de Andrade Sousa possui Licenciatura Plena em Letras Inglês pela Universidade Federal do Maranhão. Mestrando pelo Programa de Pós-Graduação em Letras da Universidade Federal do Maranhão - PPGLetras/UFMA. Integrante do Grupo de Pesquisa Ficção Científica, Gêneros Pós-modernos e Representações artísticas na Era Digital - FICÇA. Experiência na área de Letras, com ênfase em ensino de Língua Portuguesa e Literatura de Língua Portuguesa. Professor da Secretária de Estado de Educação do Maranhão (SEDUC MA). Premiado no VIII Concurso Literário de Bento Gonçalves-RS. Atualmente desenvolve pesquisas nas áreas de literatura fantástica e ficção científica.

Naiara Sales Araújo Santos possui Licenciatura Plena em Letras Inglês pela Universidade Federal do Piauí (2001), Mestrado Acadêmico em Letras pela Universidade Federal do Piauí (2007), mestrado em Estudos Literários pela Universidade Metropolitana de Londres (2008) e Doutorado em Literatura Comparada pela Universidade Metropolitana de Londres (2013). Atualmente é professora da Universidade Federal do Maranhão onde exerce a função de professora de Língua e Literatura Inglesa e coordenadora do programa Inglês Sem Fronteiras- UFMA. Tem experiência na área de Letras, com ênfase em Ensino de Língua e Literatura Estrangeira, atuando principalmente nos seguintes temas: ensino de língua inglesa, literatura, ficção Científica, literatura e cinema e estudos pós-coloniais. É lider do Grupo de Pesquisa FICÇA (Ficção Científica, Gêneros Pós-Modernos e Representação Artisticas na Era Digital) e coordenadora do Projeto de pesquisa Ficção Científica e Sociedade (UFMA). Professora do Mestrado Acadêmico em Letras da Universidade Federal do Maranhão.

N. ${ }^{\circ} 38-6 / 2018$ | 407-427 - ISSN 2183-2242 | http:/dx.doi.org/10.21747/21832242/litcomp38v6 